\title{
Docosahexaenoic Acid Inhibits Cytokine Expression by Reducing Reactive Oxygen Species in Pancreatic Stellate Cells
}

\author{
Sun Ah Chung, Joo Weon Lim, Hyeyong Kim \\ Department of Food and Nutrition, College of Human Ecology, Yonsei University, Seoul, Korea
}

\begin{abstract}
Pancreatic stellate cells (PSCs) are activated by inflammatory stimuli, such as TNF- $\alpha$ or viral infection. Activated PSCs play a crucial role in the development of chronic pancreatitis. Polyinosinic-polycytidylic acid (poly $(\mathrm{l}: \mathrm{C})$ ) is structurally similar to double-stranded RNA and mimics viral infection. Docosahexaenoic acid (DHA) exhibits anti-inflammatory activity. It inhibited fibrotic mediators and reduced NF-kB activity in the pancreas of mice with chronic pancreatitis. The present study aimed to investigate whether DHA could suppress cytokine expression in PSCs isolated from rats. Cells were pre-treated with DHA or the antioxidant $\mathrm{N}$-acetylcysteine (NAC) and stimulated with TNF- $\alpha$ or poly (I:C). Treatment with TNF- $\alpha$ or poly $(\mathrm{I}: \mathrm{C})$ increased the expression of monocyte chemoattractant protein 1 (MCP-1) and chemokine C-X3-C motif ligand 1 (CX3CL1), which are known chemoattractants, and enhanced intracellular and mitochondrial reactive oxygen species (ROS) production and NF-kB activity, but reduced mitochondrial membrane potential (MMP). Increased intracellular and mitochondrial ROS accumulation, cytokine expression, MMP disruption, and NF-kB activation were all prevented by DHA in TNF- $\alpha$ - or poly (I:C)-treated PSCs. NAC suppressed TNF- $\alpha$ - or poly (I:C)-induced expression of MCP-1 and CX3CL1. In conclusion, DHA inhibits poly (I:C)- or TNF- $\alpha$-induced cytokine expression and NF-kB activation by reducing intracellular and mitochondrial ROS in PSCs. Consumption of DHA-rich foods may be beneficial in preventing chronic pancreatitis by inhibiting cytokine expression in PSCs.
\end{abstract}

Key Words Cytokines, Docosahexaenoic acid, Pancreatic stellate cells, Reactive oxygen species

\section{INTRODUCTION}

Chronic pancreatitis is a multifactorial inflammatory syndrome in which repetitive inflammation leads to fibrotic tissue replacement. It results in chronic pain, exocrine and endocrine pancreatic insufficiency, reduced quality of life, and a shorter life expectancy [1]. This disease cannot be cured and is the most lethal disease of the pancreas $[1,2]$. Since prolonged inflammation in the pancreas is a critical factor for the development of chronic pancreatitis, it is essential to control pancreatic inflammation at an early stage to prevent chronic pancreatitis.

Pancreatic stellate cells (PSCs) exhibit quiescent and activated phenotypes. When quiescent PSCs are exposed to stimuli, such as TNF- $\alpha$, they become activated myofibroblast-like cells. Chronic activation of PSCs leads to the development of chronic pancreatitis [3]. During chronic pan- creatitis, the expression of monocyte chemoattractant protein 1 (MCP-1) and chemokine C-X3-C motif ligand 1 (CX3CL1), also known as fractalkine, is upregulated [4-6]. MCP-1 is an inflammatory chemokine that regulates monocytes and $\mathrm{T}$ lymphocytes and contributes to the pathogenesis of mononuclear infiltration [4]. CX3CL1 is a large cytokine composed of 373 amino acids. Soluble CX3CL1 potently attracts T cells and monocytes, whereas the membrane-bound chemokine promotes strong adhesion of leukocytes to activated endothelial cells. The unique functional and structural characteristics of CX3CL1 facilitate its participation in inflammation-related diseases, including atherosclerosis, rheumatoid arthritis, human immunodeficiency virus infection, and several other disorders [7]. Therefore, better understanding the roles of these chemokines in the pathogenesis of chronic pancreatitis may lead to new therapies directed towards MCP-1 and CX3CL1 regulation.

Received August 30, 2021, Revised September 25, 2021, Accepted September 27, 2021

Correspondence to Hyeyoung Kim, E-mail: kim626@yonsei.ac.kr, https://orcid.org/0000-0002-7019-917X

Check for updates 
Persistent activation of PSCs by cytokines, such as TNF- $\alpha$, during acute pancreatitis may be involved in the progression from acute pancreatitis to chronic pancreatic injury and fibrosis [8]. TNF- $\alpha$ induces the generation of reactive oxygen species (ROS) and NF- $\mathrm{kB}$ activation, leading to the expression of adhesion molecules in lung epithelial A549 cells [9]. In endothelial cells, binding of TNF- $\alpha$ to TNF receptor (TNFR) induces NF- $\kappa \mathrm{B}$ activation [10]. TNF- $\alpha$ induces CX3CL1 expression in human umbilical vein endothelial cells through the regulation of the NF-kB pathway [11]. TNF- $\alpha$ increases MCP-1 expression in PSCs, which is mediated by activator protein-1 and mitogen-activated protein kinases [12].

There are various causes of chronic pancreatitis, including viral infection [13]. Polyinosinic-polycytidilic acid (poly $(\mathrm{l}: \mathrm{C}))$ is structurally similar to double-stranded RNA, which is present in some viruses. Therefore, it has been used to mimic viral infection [14]. Poly (I:C) recognized by Toll-like receptor 3 (TLR3) induces NF- $\mathrm{KB}$ activation and MCP-1 expression in PSCs [15]. Poly (I:C)/TLR3 triggers NF- $\mathrm{B}$ activation and interleukin-6 (IL-6) production in astrocytes [16] and ROS-mediated NF- $\kappa B$ activation in macrophages [17]. Poly (I:C) induces $\mathrm{CX} 3 \mathrm{CL} 1$ expression via activation of TLR3/NF- $\mathrm{B}$ in glomerular endothelial cells [18]. These studies show the relationship between ROS and NF-kB activation or cytokine expression in cells exposed to TNF- $\alpha$ or poly (I:C).

Docosahexaenoic acid (DHA) is an omega-3 fatty acid. It can be found in cold oceanic fish oil and is synthesized from $\alpha$-linolenic acid. The anti-inflammatory effects of DHA have been reported in various inflammatory diseases, including atherosclerosis and rheumatoid arthritis [19-21]. DHA downregulates the production of inflammatory cytokines by suppressing NF- $\kappa \mathrm{B}$ nuclear translocation $[22,23]$. Previously, we have reported that $\mathrm{DHA}$ inhibits the expression of fibrotic mediators ( $\alpha$-smooth muscle actin and fibronectin) by reducing $N F-\kappa B$ expression in mouse pancreatic tissues with chronic pancreatitis [24]. DHA inhibits cerulein-induced acute pancreatitis in rats by reducing pancreatic edema, myeloperoxidase activity, levels of lipid peroxide and IL-6, and activation of NF-кB [25]. These studies show that the antioxidant activity of DHA may contribute to its inhibitory effect on pancreatic inflammation.

Since active PSCs play a critical role in the development of chronic pancreatitis by inducing inflammatory cytokines, it is essential to investigate whether DHA inhibits inflammatory cytokine expression in activated PSCs by reducing ROS and $\mathrm{NF}-\kappa \mathrm{B}$ activity in these cells.

The aim of the present study was to investigate the mechanism underlying the anti-inflammatory effect of DHA on TNF- $\alpha$ - or double-stranded RNA-induced inflammatory cytokine expression in PSCs to assess its potential as a preventive agent for inflammatory stimuli- and virus-induced chronic pancreatitis.

\section{MATERIALS AND METHODS}

\section{Animals and reagents}

Sprague- Dawley male rats (150 to $250 \mathrm{~g}$ ) at 6 weeks of age were obtained from Orient Bio (Orient Bio Inc., Seongnam, Korea). Three animals per cage were housed under a 12/12 hours light/dark cycle and provided ad libitum access to food and water. After 1 week of acclimation period, the rats were anesthetized and used as pancreas donors. All experimental procedures were approved by the Institutional Review Board (IRB) at Institutional Animal Care and Use Committee of Yonsei University (No. IACUC-A-201508-405-02).

Gey's balanced salt solution (GBSS with $\mathrm{NaCl} 7 \mathrm{~g} / \mathrm{L}$ ), protease, penicillin-streptomycin antibiotics, FBS, TNF- $\alpha$ (SRP3177), poly (I:C), (P1530), DHA (D2534), Lipofectamine 2000, 5,6-carboxy-2',7'-dichlorodihydrofluorescein diacetate (carboxy-DCF-DA) (D6883), and mounting solution (HC08) were purchased from Sigma-Aldrich (St Louis, MO, USA). The density gradient medium, Nycodenz, was purchased from Nycomed Pharmas AS (Oslo, Norway). Collagenase P and deoxyribonuclease were purchased from Roche Diagnostics GmbH (Mannheim, Germany). Dulbecco's Modified Eagle Medium nutrient mix F-12 and T4 polynucleotide kinase were purchased from Gibco (Grand Island, NY, USA). MitoSOX (M36008) and MCP-1 enzyme-linked immunosorbent assay (ELISA) kit were obtained from Invitrogen (Carlsbad, CA, USA). CX3CL1 ELISA kit was purchased from Abcam (Cambridge, UK).

\section{Isolation and culture of PSCs}

PSCs were isolated from 6-week-old male Sprague Dawley rats (150 to $250 \mathrm{~g}$ ). Briefly, the animals were sacrificed by carbon dioxide inhalation. The pancreas was dissected, removed, placed in a $50 \mathrm{~mL}$ glass beaker containing an icecold solution of $0.9 \% \mathrm{NaCl}$, trimmed of adipose and connective tissue as well as large blood vessels and moved into a biological safety cabinet. It was then transferred to a 60 $\mathrm{mm}$ plastic petri dish. Using an insulin syringe, the pancreas was injected with GBSS containing collagenase P $(0.05 \%)$, protease $(0.02 \%)$, and deoxyribonuclease $(0.1 \%)$. The tissue was incubated at $37^{\circ} \mathrm{C}$ for 4 minutes in a high-speed shaking water bath (240 cycles/ minutes) and for 3 minutes in a low-speed shaking water bath (120 cycles/ minutes). The partially digested pancreatic tissue was finely minced using scissors and incubated again at $37^{\circ} \mathrm{C}$ for 7 minutes in a shaking water bath at 120 cycles/minutes. The digested tissue was passed through a $100 \mu \mathrm{m}$ mesh and then centrifuged at $2,000 \times g$ for 5 minutes at $4^{\circ} \mathrm{C}$. After the supernatant was carefully aspirated, the cell pellet was washed with a solution containing GBSS and $\mathrm{NaCl}$ along with $0.3 \%$ bovine serum albumin (BSA), and then centrifuged at 2,000 $\times g$ for 5 minutes at $4^{\circ} \mathrm{C}$. The supernatant was carefully removed via pipetting and the cell pellet was thoroughly resuspended in $9.5 \mathrm{~mL}$ of $\mathrm{GBSS}-\mathrm{NaCl}$ solution containing $0.3 \% \mathrm{BSA}$ and 8 
$\mathrm{mL}$ of $28.7 \%$ Nycodenz solution. Six milliliters of GBSS-NaCl solution containing $0.3 \%$ BSA was taken in another centrifuge tube and the cell suspension was layered beneath using a $20 \mathrm{~mL}$ syringe, taking care not to disrupt the interface. The solution was then centrifuged at $1,400 \times g$ for 20 minutes at $4^{\circ} \mathrm{C}$. The thin white band just above the interface was collected using a 5-mL transfer pipette without disturbing the density gradient layers. Cells were washed with GBSS-NaCl solution containing $0.3 \% \mathrm{BSA}$ and centrifuged at 2,000 $\times \mathrm{g}$ for $5 \mathrm{~min}$ utes at $4^{\circ} \mathrm{C}[14,15]$. The cells were counted (approximately 3 million/g pancreas) and cultured in Dulbecco's Modified Eagle Medium nutrient mix F-12 medium supplemented with $10 \%$ FBS, $100 \mathrm{U} / \mathrm{mL}$ penicillin, and $100 \mu \mathrm{g} / \mathrm{mL}$ streptomycin in a humidified atmosphere with $5 \% \mathrm{CO}_{2}$ at $37^{\circ} \mathrm{C}$. PSCs were harvested between passages 2 and 4 after isolation for downstream analysis.

\section{Cell culture and treatment}

The cells were incubated in serum-free medium for 24 hours before treatment with TNF- $\alpha$ or poly $(\mathrm{I}: \mathrm{C})$. For poly $(\mathrm{I}: \mathrm{C})$ preparation, $10 \mu \mathrm{g}$ poly $(\mathrm{I}: \mathrm{C})$ was mixed with $5 \mu \mathrm{L}$ of Lipofectamine 2000 and $985 \mu \mathrm{L}$ of serum-free medium and incubated for 15 minutes at $21^{\circ} \mathrm{C}$ to $23^{\circ} \mathrm{C}$. TNF- $\alpha$ was dissolved in distilled water. DHA was dissolved in $0.5 \mathrm{M}$ ethanol.

\section{Experimental protocol}

For the time-course experiments, to examine the expression of MCP-1 and CX3CL1, cells $\left(1.25 \times 10^{4}\right.$ cells/well) were plated in a 6-well plate and were stimulated with TNF- $\alpha(10 \mathrm{ng} /$ $\mathrm{mL}$ ) or poly (l:C) $(1 \mathrm{mg} / \mathrm{mL})$ for 3 hours (for determination of mRNA expression) and 24 hours (for determination of protein levels).

To determine the effect of DHA on the expression of MCP1 and CX3CL1, cells $\left(1.25 \times 10^{4}\right.$ cells/well $)$ were plated in a 6-well plate and pre-treated with DHA $(10$ or $50 \mu \mathrm{M})$ for 1 hour and stimulated with TNF- $\alpha(10 \mathrm{ng} / \mathrm{mL})$ or poly $(\mathrm{I}: \mathrm{C})(1$ $\mathrm{mg} / \mathrm{mL}$ ) for 1 hour (for determination of intracellular and $\mathrm{mi}$ tochondrial ROS levels, mitochondrial membrane potential [MMP], and NF-kB activity), 3 hours (for determination of mRNA expression), and 24 hours (for determination of protein levels). The 1 hour-culture time for evaluating ROS levels and $\mathrm{NF}-\mathrm{kB}$ activation was adapted from previous studies that used cells stimulated with TNF- $\alpha$ or poly $(\mathrm{I}: C)[9,10,16,17]$.

\section{Real-time PCR (RT-PCR)}

The gene expression levels of MCP-1 and CX3CL1 were assessed by real-time PCR. Total RNA was isolated using the TRI reagent (RNA/DNA/protein isolation reagent, Molecular Research Center, Cincinnati, OH, USA) and reverse-transcribed into cDNA using a random hexamer and M-MLV reverse transcriptase (Promega, Madison, WI, USA) at $23^{\circ} \mathrm{C}$ for 10 minutes, $42^{\circ} \mathrm{C}$ for 60 minutes, and $95^{\circ} \mathrm{C}$ for 5 minutes. The CDNA was incubated with SYBR Green Real-time PCR Master Mix (Toyobo, Osaka, Japan) containing $10 \mathrm{pg} / \mathrm{mL}$ of forward and reverse primers, and amplified using the Light Cycler PCR system (Roche Applied Sciences, Indianapolis, IN, USA). RT-PCR was performed using the following rat-specific primers for MCP-1: 5'-ACGTGCTGTCTCAGCCAGAT-3' (forward) and 5'-GTTCTCCAGCCGACTCAT TG3' (reverse), CX3CL1: 5'-CACAAGATGACCTCGCCAAT-3' (forward) and 5'-GCTGTCTCGTCTCCAGGATG-3' (reverse) and glyceraldehyde-3-phosphate dehydrogenase (GAPDH): 5'-GCTCTCTGCTCCTCCCTGTT-3' (forward) and 5'-CACACCGACCTTCACCATCT-3' (reverse). For PCR amplification, the cDNA was amplified by 40 cycles of denaturation at $95^{\circ} \mathrm{C}$ for 30 seconds, annealing at $54^{\circ} \mathrm{C}$ for 30 seconds, and extension at $72^{\circ} \mathrm{C}$ for 45 seconds. During the first cycle, the $95^{\circ} \mathrm{C}$ step was extended to 3 minutes. GAPDH was amplified in the same reaction as the reference gene.

\section{Measurement of intracellular ROS levels}

Intracellular ROS levels were assessed using carboxy-DCFDA. The cells were incubated with $5 \mu \mathrm{M}$ carboxy-DCF-DA for 1 hour. Cells were washed twice and harvested with PBS and plated into black $96-$ well plates. The change in fluorescence was measured using a fluorometer (VICTOR 5 Wallac 1420 multi-label counter, Perkin Elmer Life and Analytical Sciences, Waltham, MA, USA) at excitation and emission wavelengths of 485 and $535 \mathrm{~nm}$, respectively.

\section{Measurement of mitochondrial ROS levels} MitoSOX was used to assess mitochondrial ROS levels. The cells were incubated with $2 \mu \mathrm{M}$ MitoSOX for 1 hour, washed twice, harvested with PBS, and plated into black 96-well plates. The change in fluorescence was measured using a fluorometer (VICTOR 5 Wallac 1420 multi-label counter, Perkin Elmer Life and Analytical Sciences at excitation and emission wavelengths of 514 and $585 \mathrm{~nm}$, respectively.

\section{Fluorescence detection of MMP}

Tetraethyl benzimidazolyl carbocyanine iodide (JC-1) is a novel cationic carbocyanine dye that accumulates in the mitochondria and can be used to measure MMP. For laser-scanning confocal microscopy, the cells $\left(1.25 \times 10^{4}\right.$ cells $)$ were seeded on a glass slide and then treated with DHA $(50 \mu \mathrm{M})$ for 1 hour prior to treatment with TNF- $\alpha(10 \mathrm{ng} / \mathrm{mL})$ or poly (I:C) $(1 \mu \mathrm{g} / \mathrm{mL})$ for 1 hour. The cells were stained with JC-1 fluorescent dye, washed with PBS, and mounted on microscope slides with mounting solution. Images were obtained by confocal microscopy (Zeiss LSM 510; Carl Zeiss Inc., Thornwood, NY, USA) at an excitation wavelength of $514 \mathrm{~nm}$ and emission wavelength of $529 \mathrm{~nm}$ and overlaid using the LSM software.

\section{Electrophoretic mobility shift assay}

PSCs were rinsed with ice-cold PBS, harvested by trypsinization, and pelleted by centrifugation at 5,000 $\times g$ for 5 minutes. Cells were then lysed in a buffer containing $10 \mathrm{mM}$ HEPES, 
$10 \mathrm{mM} \mathrm{KCl}, 1.5 \mathrm{mM} \mathrm{MgCl} 2,0.05 \%$ Nonidet P-40, $0.5 \mathrm{mM}$ dithiothreitol (DTT), and $0.5 \mathrm{mM}$ phenylmethylsulfonyl fluoride, and centrifuged at $13,000 \times g$ for 10 minutes. The pellets were resuspended in nuclear extraction buffer containing 10 mM HEPES, $420 \mathrm{mM} \mathrm{NaCl}, 0.2 \mathrm{mM}$ EDTA, $1.5 \mathrm{mM} \mathrm{MgCl}_{2}$, $25 \%$ glycerol, $0.2 \mathrm{mM}$ DTT, and $0.5 \mathrm{mM}$ phenylmethylsulfonyl fluoride, and clarified by centrifugation at $13,000 \times g$ for 10 minutes. The supernatants were collected and used as nuclear extracts. Protein concentration was determined by the Bradford assay (Bio-Rad Laboratories, Hercules, CA, USA). An NF- $\kappa B$ gel shift oligonucleotide (5'-AGTTGAGGGGACTTTCCCAGGC-3'; Promega, Madison, WI, USA) was labeled with $\left[{ }^{32} \mathrm{P}\right]$ dATP (Amersham Biosciences, Piscataway, NJ, USA) using T4 polynucleotide kinase. The end-labeled probe was purified from unincorporated $\left[{ }^{32} \mathrm{P}\right] \mathrm{dATP}$ using a Bio-Rad purification column (Bio-Rad Laboratories) and recovered in Tris-EDTA (TE) buffer. Nuclear extracts $(0.5 \mu \mathrm{g})$ were preincubated with the buffer containing $12 \%$ glycerol, 12
mM HEPES (pH 7.9), 1 mM EDTA, 1 mM DTT, 25 mM KCl, $5 \mathrm{mM} \mathrm{MgCl}_{2}$, and $0.04 \mu \mathrm{g} / \mathrm{mL}$ poly-deoxy-inosinic-deoxy-cytidylic acid for 30 minutes at $21^{\circ} \mathrm{C}$ to $23^{\circ} \mathrm{C}$. The samples were subjected to electrophoretic separation at $4^{\circ} \mathrm{C}$ on a non-denaturing $5 \%$ acrylamide gel. The gel was dried at $80^{\circ} \mathrm{C}$ for 2 hours and exposed to a radiography film for 5 to 8 days at $-80^{\circ} \mathrm{C}$ with intensifying screens.

\section{ELISA}

The levels of MCP-1 or CX3CL1 in the cell culture medium were determined using the MCP-1 ELISA kit or CX3CL1 ELISA kit, according to the manufacturer's instructions.

\section{Statistical analysis}

All data are expressed as the mean \pm SE. All experiments were repeated three times. Number of each group was four. The statistical differences among groups were evaluated by one-way ANOVA followed by Tukey's test. Statistical anal-
A

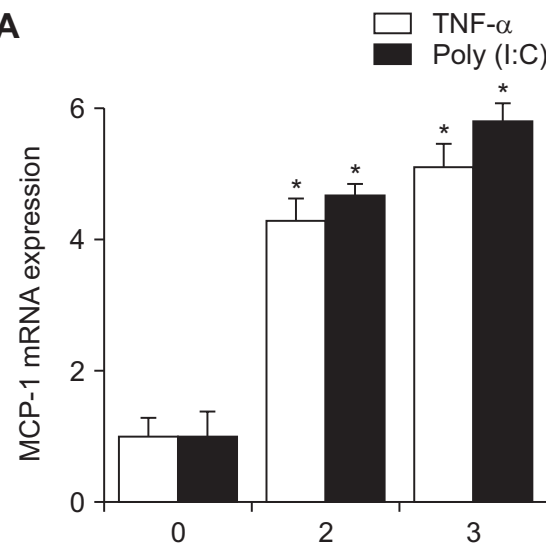

(h)
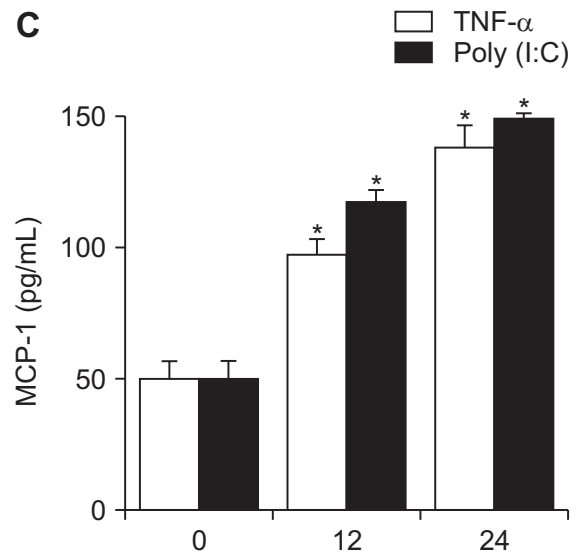

(h)
B

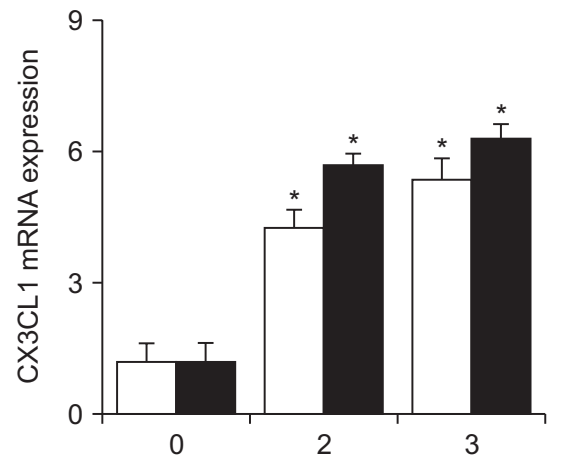

(h)
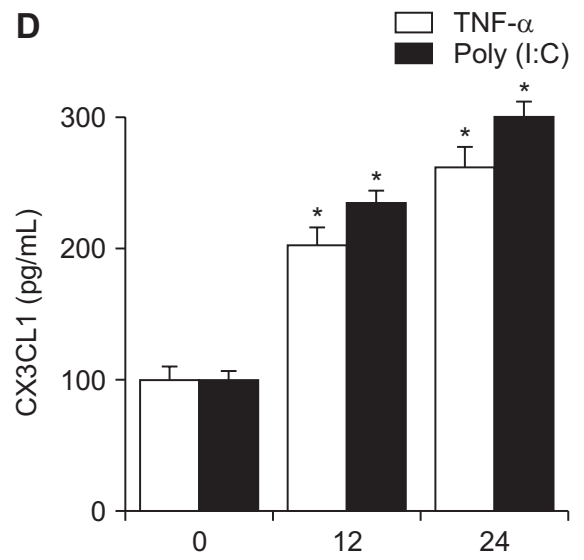

(h)

Figure 1. TNF- $\alpha$ and poly (I:C) induce the expression of MCP-1 and CX3CL1 in pancreatic stellate cells (PSCs). Cells were treated with TNF- $\alpha$ at $10 \mathrm{ng} / \mathrm{mL}$ or poly (I:C) at $1 \mu \mathrm{g} / \mathrm{mL}$ for the indicated time periods. (A, B) mRNA expression was determined by real-time PCR analysis and normalized to that of glyceraldehyde-3-phosphate dehydrogenase (GAPDH). (C, D) Protein levels in the medium were determined by enzymelinked immunosorbent assay (ELISA). Data are expressed as the mean \pm SE. MCP-1, monocyte chemoattractant protein 1; poly (I:C), polyinosinicpolycytidylic acid; NAC, N-acetylcysteine; CX3CL1, chemokine C-X3-C motif ligand 1. ${ }^{*} P<0.05$ vs. 0 hour. 
ysis was performed using SPSS 22.0 software (IBM Corp., Armonk, NY, USA). $P<0.05$ was considered to indicate a statistically significant difference.

\section{RESULTS}

\section{TNF- $\alpha$ and poly (I:C) induce the expression of} MCP-1 and CX3CL1 in PSCs

RT-PCR and ELISA were performed to establish the effect of TNF- $\alpha(10 \mathrm{ng} / \mathrm{mL})$ or poly $(\mathrm{l}: \mathrm{C})(1 \mu \mathrm{g} / \mathrm{mL})$ on the mRNA and protein expression of MCP-1 and CX3CL1 (Fig. 1). Both TNF- $\alpha$ and poly (I:C) treatment increased the relative mRNA and protein levels of MCP-1 and CX3CL1 in a time-dependent manner. Maximal MCP-1 and CX3CL1 mRNA expression was observed after 3 hours of incubation (Fig. $1 \mathrm{~A}$ and 1B). Protein levels of MCP-1 and CX3CL1 were highest at
24 hours of culture (Fig. 1C and 1D). These results indicated that TNF- $\alpha$ and poly $(\mathrm{I}: \mathrm{C})$ induced the expression of MCP-1 and $\mathrm{CX} 3 \mathrm{CL} 1$ in a time-dependent manner. Therefore, to investigate the effect of DHA, cells were stimulated with TNF- $\alpha$ (10 $\mathrm{ng} / \mathrm{mL}$ ) or poly (I:C) $(1 \mu \mathrm{g} / \mathrm{mL}$ ) for 3 hours (for measuring mRNA expression) and 24 hours (for determination of protein levels in the medium) in the following experiments.

\section{DHA suppresses TNF- $\alpha$ - or poly (I:C)-induced expression of MCP-1 and CX3CL1 in PSCs}

RT-PCR was performed to investigate the inhibitory effect of DHA on the expression of MCP-1 and CX3CL1 mRNA in PSCs. The cells were pre-treated with DHA $(10,50 \mu \mathrm{M})$ for 1 hour and then incubated with TNF- $\alpha(10 \mathrm{ng} / \mathrm{mL})$ or poly $(\mathrm{I:C})$ $(1 \mu \mathrm{g} / \mathrm{mL}$ ) for 3 hours (Fig. 2A and 2B). TNF- $\alpha$ or poly (I:C) increased the mRNA expression of MCP-1 and CX3CL1, and
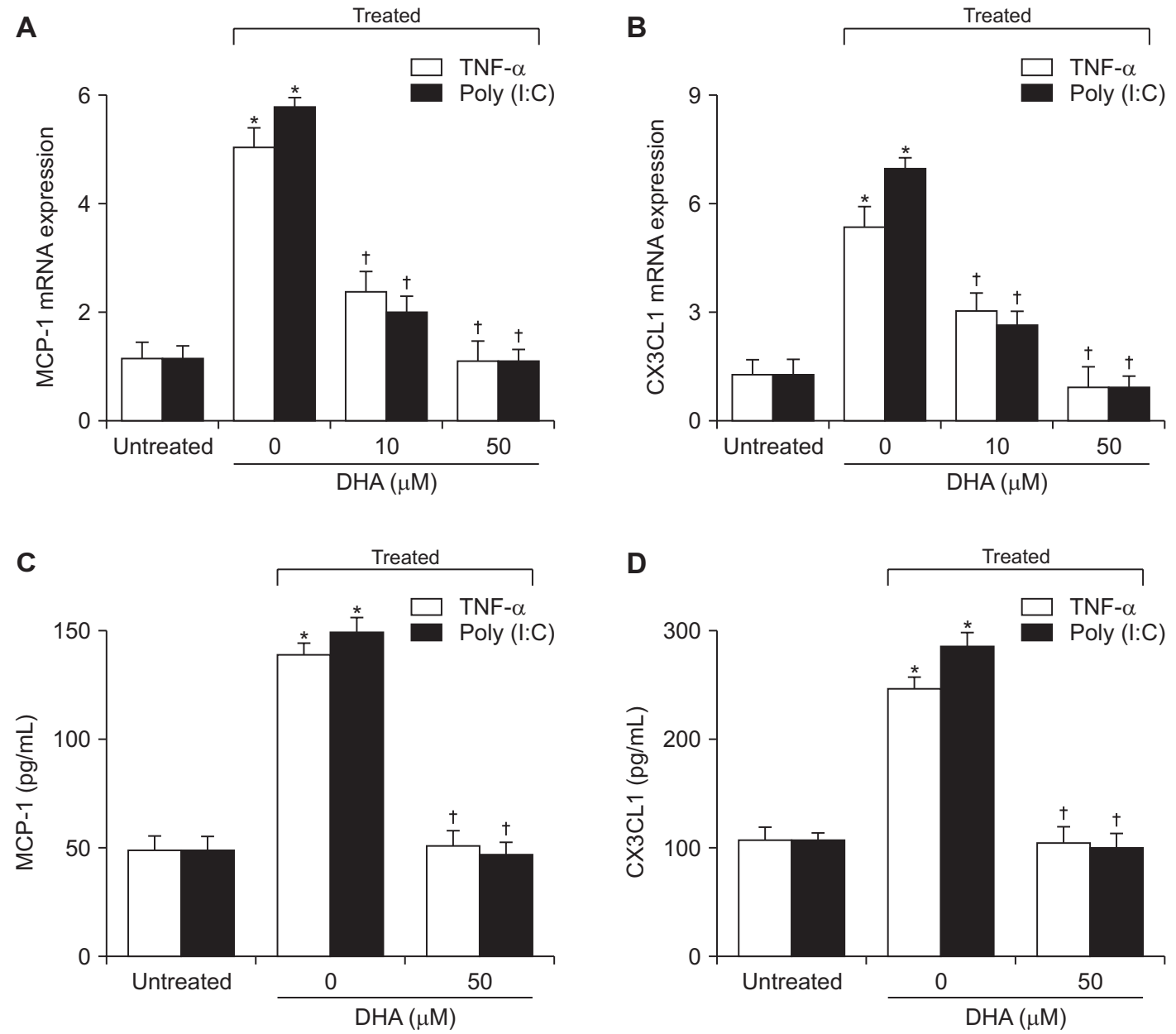

Figure 2. DHA inhibits TNF- $\alpha-$ and poly (I:C)-induced expression of MCP-1 and CX3CL1 in pancreatic stellate cells (PSCs). (A, B) The cells were pre-treated with the indicated concentrations of DHA and stimulated with TNF- $\alpha(10 \mathrm{ng} / \mathrm{mL})$ or poly $(\mathrm{I}: \mathrm{C})(1 \mu \mathrm{g} / \mathrm{mL})$ for $3 \mathrm{hours}$. $\mathrm{mRNA}$ expression was determined by real-time PCR analysis and normalized to that of glyceraldehyde-3-phosphate dehydrogenase (GAPDH). (C, D) The cells were pre-treated with DHA $(50 \mu \mathrm{M})$ and stimulated with TNF- $\alpha(10 \mathrm{ng} / \mathrm{mL})$ or poly $(\mathrm{I}: \mathrm{C})(1 \mu \mathrm{g} / \mathrm{mL})$ for 24 hours. Protein levels in the medium were determined by enzyme-linked immunosorbent assay (ELISA). Data are expressed as the mean \pm SE. MCP-1, monocyte chemoattractant protein 1 ; poly (I:C), polyinosinic-polycytidylic acid; DHA, docosahexaenoic acid; CX3CL1, chemokine C-X3-C motif ligand $1 .{ }^{*} P<0.05$ vs. untreated cells; ${ }^{\dagger} P<$ 0.05 vs. cells treated with $\mathrm{TNF}-\alpha$ or poly $(\mathrm{I}: \mathrm{C})$ alone. 
this increase was significantly reduced by DHA in a concentration-dependent manner. ELISA was performed to evaluate whether DHA could suppress TNF- $\alpha$ - or poly (I:C)-induced increase of MCP-1 and CX3CL1 protein levels. The cells were pre-treated with DHA $(50 \mu \mathrm{M})$ for 1 hour and then incubated with TNF- $\alpha$ or poly (I:C) for 24 hours. TNF- $\alpha$ - or poly (I:C)-induced increases of the protein levels of MCP-1 and CX3CL1 were significantly reduced by DHA (Fig. 2C and 2D). These results indicated that DHA inhibited TNF- $\alpha$ - and poly (I:C)-induced expression of MCP-1 and CX3CL1 at both mRNA and protein levels.

\section{DHA attenuates TNF- $\alpha$ - or poly (I:C)-induced increase of intracellular and mitochondrial ROS levels and decrease of mitochondrial membrane potential (MMP) in PSCs}

We measured intracellular and mitochondrial ROS levels in cells stimulated with TNF- $\alpha$ or poly (I:C) for 1 hour (Fig. 3). Intracellular ROS levels in the cells treated with TNF- $\alpha$ or poly $(\mathrm{I}: \mathrm{C})$ (control) were $100 \%$ to $120 \%$ higher than those of untreated cells (none), whereas ROS levels in the mitochondria increased by $100 \%$ to $150 \%$ in cells treated with TNF- $\alpha$ or poly (I:C). Pre-treatment with DHA $(50 \mu \mathrm{M})$ prevented these reductions in intracellular ROS (Fig. 3A) and in mitochondrial ROS (Fig. 3B).

To further examine whether TNF- $\alpha$ or poly $(\mathrm{I}: \mathrm{C})$ treatment causes impairment of MMP, the cells were treated with 5,5',6,6'-tetrachloro-1,1',3,3'-JC-1 and then observed under a confocal microscope. As shown in Figure 4A, the red fluorescence observed in the cells indicates mitochondria with high MMP, whereas the green fluorescence indicates mitochondria with low MMP. The ratio of the intensities of the red and green fluorescence shown in Figure 4B indicates that the MMP was decreased by $40 \%$ in TNF- $\alpha$-treated cells and by $30 \%$ in poly (I:C)-treated cells. DHA pre-treatment suppressed this decrease. These results indicated that DHA reduced the levels of intracellular and mitochondrial ROS as well as attenuated mitochondrial dysfunction in TNF- $\alpha$ - or poly (I:C)-treated PSCs.

\section{DHA inhibits TNF- $\alpha$ or poly (I:C)-induced activation of NF-KB in PSCs}

Next, we determined the active nuclear NF- $\mathrm{B}$ formed in cells pre-treated with DHA for 1 hour and stimulated with TNF- $\alpha$ or poly (I:C) for 1 hour. As shown in Figure 5, NF-кB-DNA binding activity was increased by treatment with TNF- $\alpha$ or poly (I:C). Pre-treatment of cells with DHA suppressed TNF- $\alpha$ - or

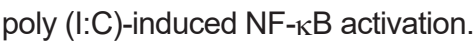

\section{NAC suppresses TNF- $\alpha$ - or poly (I:C)-induced expression of MCP-1 and CX3CL1 in PSCs}

To assess the role of ROS on cytokine expression, we determined whether the antioxidant $\mathrm{N}$-acetylcysteine (NAC) suppresses the expression of MCP-1 and CX3CL1 in cells stimulated with TNF- $\alpha$ or poly (I:C). The cells were pre-treated with NAC for 1 hour and treated with TNF- $\alpha$ or poly (I:C) for 3 hours (Fig. 6A and 6B) and 24 hours, respectively (Fig. 6C and 6D). NAC suppressed both mRNA and protein expression of MCP-1 and CX3CL-1 in cells stimulated by TNF- $\alpha$ or poly (I:C). These results suggested that TNF- $\alpha-$ or poly (I:C)-induced expression of MCP-1 and CX3CL1 may be mediated by ROS.
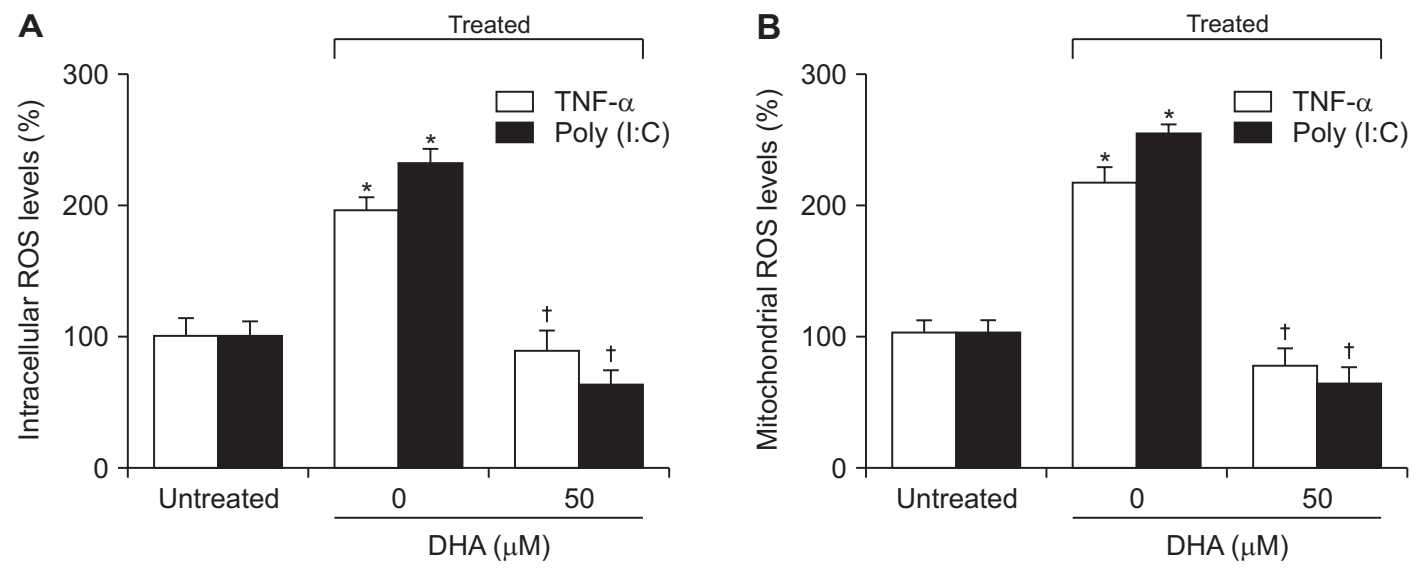

Figure 3. Effect of DHA on TNF- $\alpha$ - or poly (I:C)-induced increase in intracellular and mitochondrial ROS levels in pancreatic stellate cells (PSCs). PSCs were pre-treated with $50 \mu \mathrm{M} \mathrm{DHA}$ for 1 hour, and then stimulated with TNF- $\alpha(10 \mathrm{ng} / \mathrm{mL})$ or poly $(\mathrm{l}: \mathrm{C})(1 \mu \mathrm{g} / \mathrm{mL})$ for $1 \mathrm{hour}$. (A) Intracellular ROS levels were determined by 5,6-carboxy-2',7'-dichlorodihydrofluorescein diacetate (DCF-DA) assay. (B) Mitochondrial ROS levels were measured using MitoSOX reagent (Invitrogen, Carlsbad, CA, USA). Data are expressed as the mean \pm SE. ROS, reactive oxygen species; poly (I:C), polyinosinic-polycytidylic acid; DHA, docosahexaenoic acid. ${ }^{*} P<0.05$ vs. untreated cells; ${ }^{\dagger} P<0.05$ vs. cells treated with TNF- $\alpha$ or poly (I:C) alone. 
A
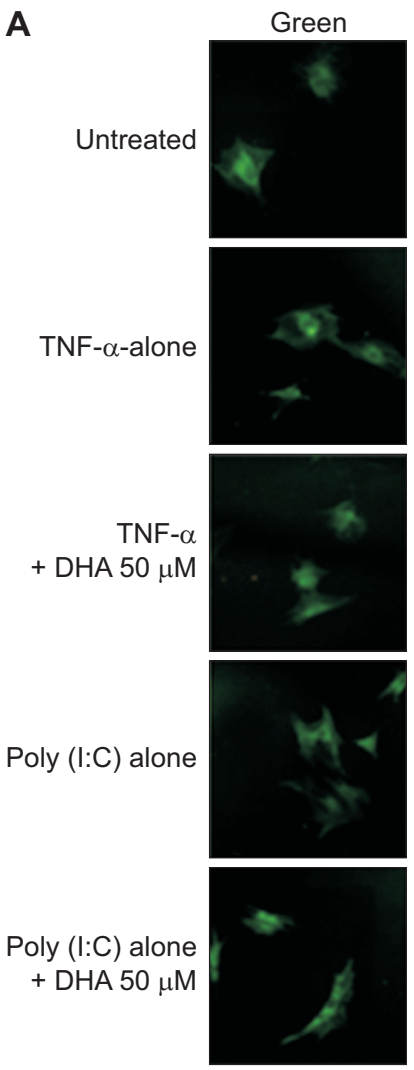

Red
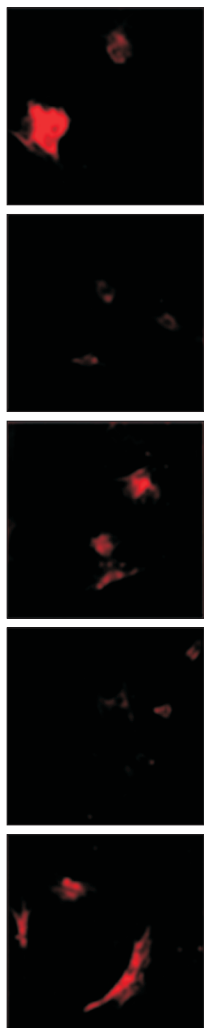

Merge
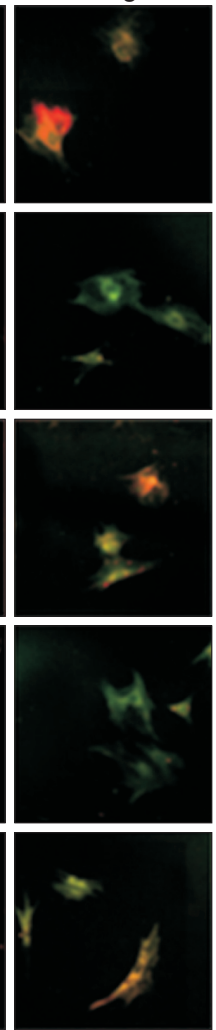

B

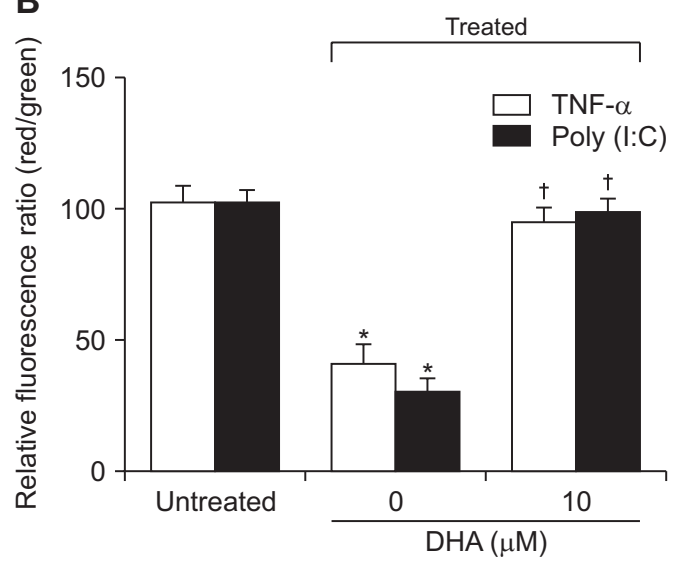

Figure 4. Effect of DHA on TNF- $\alpha$ - or poly (I:C)-induced disruption of mitochondrial membrane potential (MMP) in pancreatic stellate cells (PSCs). MMP was determined by confocal microscopy of cells pre-treated with DHA (50 $\mu \mathrm{M})$ for 1 hour and stimulated with TNF- $\alpha(10 \mathrm{ng} / \mathrm{mL})$ or poly (I:C) $(1 \mu \mathrm{g} / \mathrm{mL})$ for 1 hour prior to staining with JC-1 fluorescent dye ( $\times 200$ magnification). (A) High MMP is indicated by red fluorescence and low MMP by green fluorescence. (B) The ratio of the intensities of red to green fluorescence was determined for the images shown in the (A). Values are expressed as the mean \pm SE. DHA, docosahexaenoic acid; poly $(\mathrm{I}: \mathrm{C})$, polyinosinic-polycytidylic acid. ${ }^{*} P<0.05$ vs. untreated cells; ${ }^{\dagger} P<0.05$ vs. cells treated with TNF- $\alpha$ or poly $(\mathrm{I}: \mathrm{C})$ alone.

A

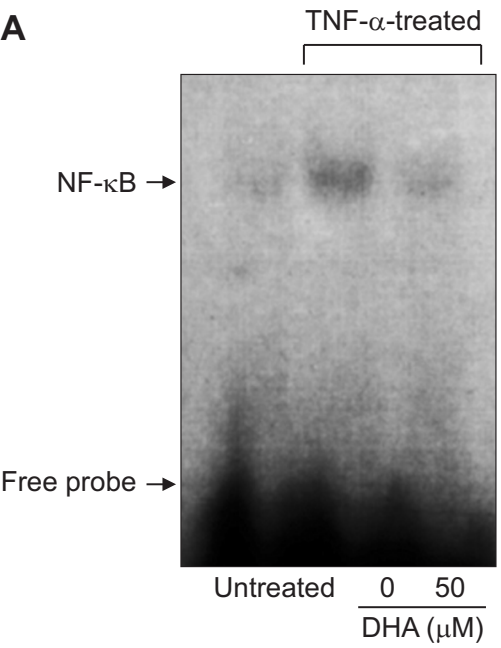

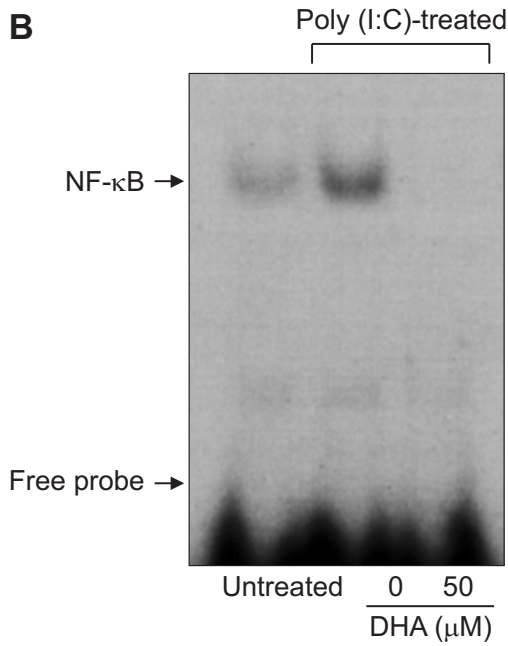

Figure 5. Effect of DHA on TNF- $\alpha$ or poly (I:C)-induced activation of NF-KB in pancreatic stellate cells (PSCs). The cells were pre-treated with $50 \mu \mathrm{M}$ DHA for 1 hour and then stimulated with TNF- $\alpha(10 \mathrm{ng} / \mathrm{mL})(\mathrm{A})$ or poly (I:C) $(1 \mu \mathrm{g} / \mathrm{mL})(B)$ for 1 hour. $\mathrm{NF}-\kappa \mathrm{B}-\mathrm{DNA}$ binding activity in the nuclear extracts was determined by electrophoretic mobility shift assay. DHA, docosahexaenoic acid; poly (I:C), polyinosinic-polycytidylic acid.

\section{DISCUSSION}

In the present study, we showed that TNF- $\alpha$ and poly (I:C) induced the expression of MCP-1 and CX3CL1 and that DHA inhibited this upregulation in PSCs. MCP-1 and CX3CL1 levels are increased in chronic pancreatitis $[26,27]$. These two cytokines regulate monocytes and $T$ lymphocytes and contribute to the pathogenesis of pancreatitis $[4,7]$. TNF- $\alpha$ 
A

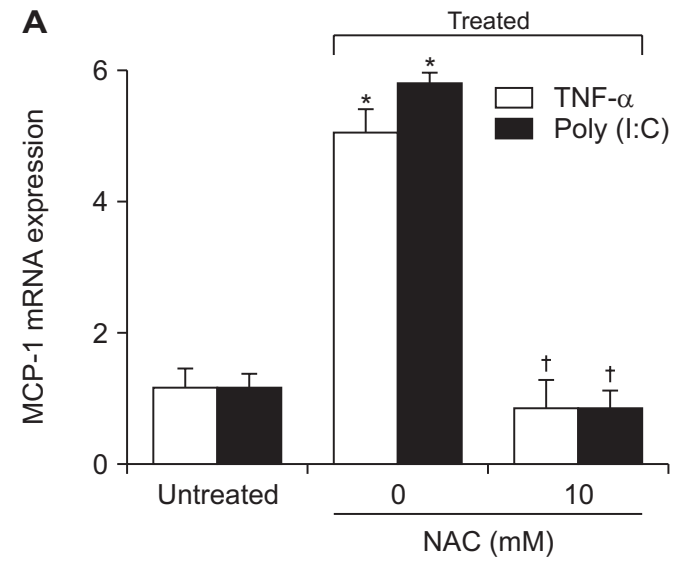

C

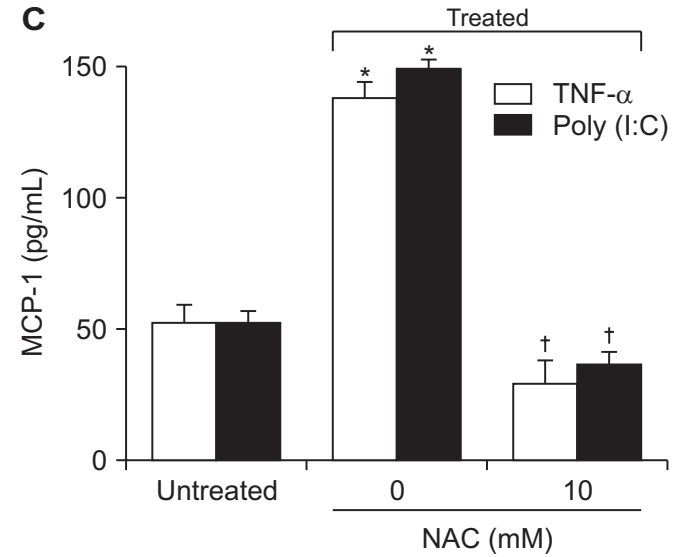

B

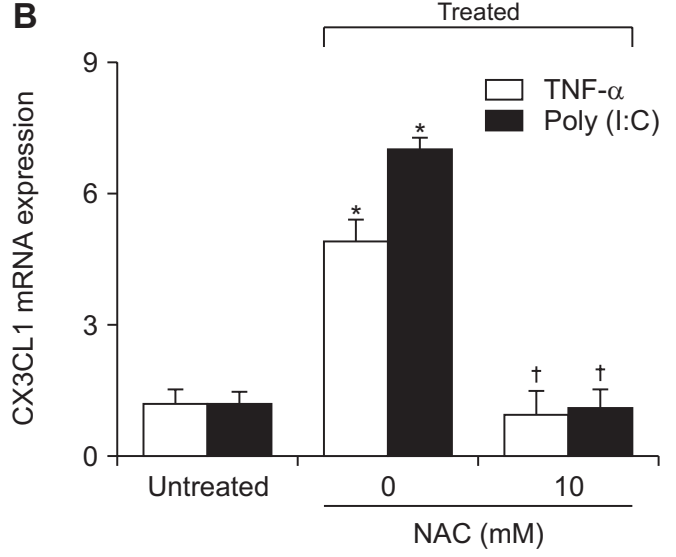

D

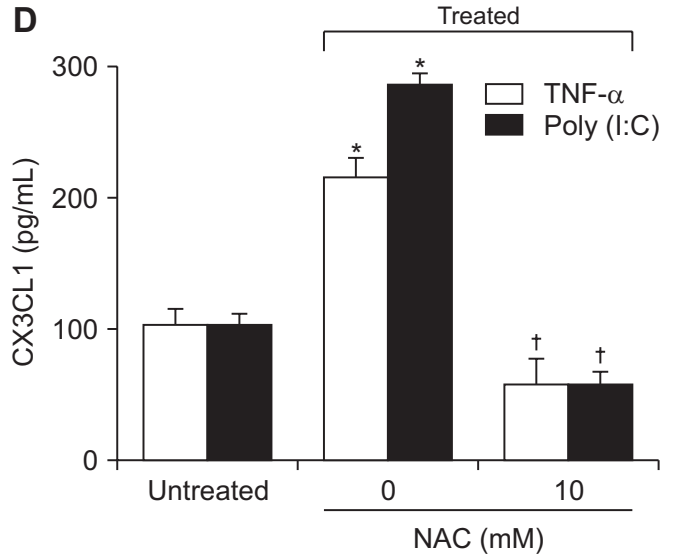

Figure 6. Effect of the antioxidant $\mathrm{N}$-acetylcysteine (NAC) on TNF- $\alpha$ - or poly (I:C)-induced expression of MCP-1 and CX3CL1 in pancreatic stellate cells (PSCs). (A, B) The cells were pre-treated with NAC $(10 \mathrm{mM})$ and stimulated with TNF- $\alpha(10 \mathrm{ng} / \mathrm{mL})$ or poly $(\mathrm{l}: \mathrm{C})(1 \mu \mathrm{g} / \mathrm{mL})$ for 3 hours. mRNA expression was determined by real-time PCR analysis and normalized to that of GAPDH. (C, D) The cells were pre-treated with NAC $(10 \mathrm{mM})$ and stimulated with TNF- $\alpha(10 \mathrm{ng} / \mathrm{mL})$ or poly $(\mathrm{I}: \mathrm{C})(1 \mu \mathrm{g} / \mathrm{mL})$ for 24 hours. Protein levels in the medium were determined by enzymelinked immunosorbent assay (ELISA). Data are expressed as the mean $\pm \mathrm{SE}$. MCP-1, monocyte chemoattractant protein 1; poly (I:C), polyinosinicpolycytidylic acid, CX3CL1, chemokine C-X3-C motif ligand $1 .{ }^{*} P<0.05$ vs. untreated cells; ${ }^{\dagger} P<0.05$ vs. cells treated with TNF- $\alpha$ or poly (I:C) alone.

and poly $(\mathrm{I}: \mathrm{C})$ induced an inflammatory response and DHA suppressed this effect, suggesting that DHA might prevent the development of chronic pancreatitis. However, the mechanism by which TNF- $\alpha$ and poly (I:C) induce cytokine expression in PSCs and the process by which DHA reduces inflammation are not fully understood.

In the present study, we demonstrated that treatment with TNF- $\alpha$ or poly $(\mathrm{I}: \mathrm{C})$ increased intracellular and mitochondrial ROS levels. Excessive production of ROS is associated with inflammatory diseases, and mitochondrial ROS impacts the expression of proinflammatory cytokines [28-33]. Mitochondria are also known to be targets of ROS. Uncontrolled overproduction of ROS can impair the mitochondria [34]. A recent study showed that increased intracellular ROS cause mitochondrial dysfunction and a subsequent increase in the production of mitochondrial ROS [35]. Mitochondrial ROS activate inflammatory signaling pathways to induce proinflammatory cytokines and inflammasome formation [36-38]. Here, we found that TNF- $\alpha$ and poly (I:C) treatment resulted in dysfunctional MMP and increased mitochondrial ROS, which were reduced by DHA treatment. NAC, a known antioxidant, prevented TNF- $\alpha$ - and poly (I:C)-induced cytokine expression in PSCs. This indicated that increased production of ROS induced the upregulation of inflammatory cytokine expression and that DHA reduced the expression of inflammatory cytokines by reducing $\mathrm{ROS}$ levels.

$\mathrm{NF}-\mathrm{kB}$ is a transcription factor that influences inflammation by regulating the production of proinflammatory cytokines [39]. ROS also influence inflammation and activate NF-kB signaling [40]. Huang et al. [41] have reported that prolonged activation of NF-kB correlates with the development and severity of chronic pancreatitis.

In the present study, we found that TNF- $\alpha$ and poly (I:C) induced NF-kB activation, and DHA inhibited this activation. Our results suggest that TNF- $\alpha$ and poly $(\mathrm{I}: \mathrm{C})$ increase inflammatory cytokine expression by activating NF-kB, which is induced by the production of intracellular and mitochondrial ROS, and that DHA reduces this inflammatory response by 
reducing ROS levels and preventing mitochondrial dysfunction. Since high amounts of intracellular ROS can damage mitochondria and thus increase mitochondrial ROS [34,35], reducing intracellular ROS might prevent the disruption of mitochondria and thus, decrease mitochondrial ROS in PSCs.

Signals mediating TNF- $\alpha$-induced NF-kB activation are initiated by the engagement of TNFR at the plasma membrane and then relayed through specific TNFR-associated proteins. TNF- $\alpha$-associated death domain-containing protein is an adaptor protein that interacts with TNFR and is required for TNF- $\alpha$-mediated induction of NF-kB [42]. TNF- $\alpha$ (10 ng/ $\mathrm{mL}$ ) induced the expression of adhesion molecules, such as intracellular adhesion molecule-1 (ICAM-1) via ROS-mediated NF- $k B$ activation in lung epithelial cells [9] and endothelial cells [10]. TNF- $\alpha$ induced NF-kB activation in pancreatic acinar cells [43]. PSCs express ICAM-1 mainly through the activation of $\mathrm{NF}-\mathrm{KB}$, thus playing a role in the pathogenesis of pancreatic inflammation [44].

Regarding poly $(I: C)$ signaling, the viral mimic poly $(I: C)$, a synthetic analog of dsRNA, activates the TLR3 pathway [45]. Poly (I:C)-mediated expression of cytokines, such as IL-6 and MCP-1, is mediated by NF-kB in corneal fibroblasts [46]. In the pancreas, viral infections have been suggested as potential mediators of $\beta$-cell death in early type 1 diabetes mellitus. Poly $(\mathrm{I}: \mathrm{C})$ activates NF- $\mathrm{KB}$, which induces the expression of inducible nitric oxide synthase and cell apoptosis [47]. These studies demonstrated the ROS-NF-kB-cytokine axis in TNF- $\alpha$ - or poly (I:C)-stimulated cells, which supports the present finding that increased intracellular and mitochondrial ROS induce NF-kB activation and cytokine expression in PSCs. In addition, we found that mitochondrial ROS are related to mitochondrial dysfunction, as determined by the reduction of MMP, in PSCs exposed to TNF- $\alpha$ or poly (I:C).

MCP-1 is a major chemokine expressed during pancreatitis [48] and reflects the severity of acute and chronic pancreatitis $[49,50]$. CX3CL1 activates PSCs and the levels of CX3CL1 increase during acute and chronic pancreatitis [51]. In the present study, we found that TNF- $\alpha$ or poly (I:C) treatment increased MCP-1 and CX3CL1 expression. In addition, TNF- $\alpha$ or poly $(\mathrm{I}: \mathrm{C})$ treatment increased intracellular and mitochondrial ROS and NF-kB activity, but decreased MMP in PSCs. These results show that inflammatory stimuli- or viral infection- induced expression of MCP-1 and CX3CL1 is dependent on ROS-mediated NF-kB activation and mitochondrial dysfunction in PSCs.

Regarding the antioxidant and anti-inflammatory effects of DHA, we previously showed that in cerulein-stimulated AR42J cells, DHA reduces ROS levels and induces catalase expression via activation of PPAR- $\gamma$ [52]. Activation of PPAR- $\gamma$ results in the inhibition of MCP-1 expression in PSCs [53]. The activation of PPAR- $\gamma$ by rosiglitazone in macrophages repressed the transcription of CX3CL1 gene and prevented plasma membrane translocation, suggesting that PPAR- $\gamma$ activation may suppress CX3CL1 signaling [54]. Thus, DHA may decrease ROS levels by activating PPAR- $\gamma$ in activated PSCs. Further studies are required to determine whether DHA activates PPAR- $\gamma$ and induces its target gene catalase to reduce ROS levels in activated PSCs.

Intracellular ROS levels can be detected using carboxyDCF-DA. The change in fluorescence can be measured using a fluorometer or a confocal microscope as a fluorescence photograph. In the present study, intracellular ROS levels were determined using fluorometer since this method determines the changes of ROS quantitatively. Determining a fluorescence photograph may be useful as a supportive way for determining intracellular ROS for the further study.

Several studies demonstrated that TNF- $\alpha$ activated radical production in mitochondria principally at the ubiquinone site and TNF- $\alpha$ damages the mitochondrial chain at complex III, which consequently results in the increased production of mitochondrial ROS inside the mitochondrion in several cell lines [55-57]. Unger et al. [58] reported that poly (I:C) induced production of mitochondrial ROS in bronchial epithelial cells. The data suggest that TNF- $\alpha$ and poly $(\mathrm{I}: \mathrm{C})$ may induce production of mitochondrial ROS by damaging the mitochondrial chain at complex III in PSCs. These studies support the present findings that show the increase mitochondrial ROS in PSCs stimulated with TNF- $\alpha$ or poly (I:C).

In the present study, the ROS induction rate in mitochondria is slightly higher than intracellular ROS. It may be explained by the method to detect ROS. Intracellular and mitochondrial ROS levels were measured using carboxy-DCF-DA and MitoSOX, respectively. Carboxy-DCF-DA can determine ROS in the cytosol and penetrate the outer mitochondrial membrane. MitoSOX is able to enter the mitochondrial matrix [59]. Therefore, there can be differences between induction rates of intracellular and mitochondrial ROS. Several studies reported that the ROS induction rate in mitochondria was higher than intracellular ROS in the cells exposed to oxidative stress [60,61].

PSC can be evaluated by immunocytochemistry using antibodies specific for PSC markers such as $\alpha$-smooth muscle actin $(\alpha-S M A)[62,63]$. Activated PSCs have increased $\alpha$-SMA. In the present study, we used the cells that present $\alpha$-SMA using immunocytochemistry, which was demonstrated in our previous study [64]. In addition, in the present study, NF- $\kappa B$ bands were confirmed using a cold probe or competition reaction as described in our previous study [65].

Regarding the effect of DHA on ROS levels, the low concentration of DHA $(\leq 60 \mu \mathrm{M})$ had ROS-scavenging activity $[66,67]$ and antioxidant activity [68] whereas the high concentration of DHA ( $\geq 100 \mu \mathrm{M})$ has prooxidant activity [69]. For cytotoxicity of DHA, DHA (50 $\mu$ M) has cytotoxic effects in cancer cell lines, whereas high concentrations of DHA (> $100 \mu \mathrm{M})$ did not affect the viability of normal cells $[70,71]$. The data suggest that DHA $(50 \mu \mathrm{M})$ may not be cytotoxic to PSCs isolated form rat pancreas. In the present study, viable cell numbers were not changed by DHA $(50 \mu \mathrm{M})$ for 24 hour-cul- 
ture.

In conclusion, DHA reduces the magnitude of the inflammatory response in PSCs induced by TNF- $\alpha$ or poly (I:C) treatment, which causes increased levels of intracellular and mitochondrial ROS, NF- $\mathrm{KB}$ activation, and MCP-1 and CX$3 \mathrm{CL} 1$ expression. These findings suggest that consumption of DHA-rich foods and DHA supplementation may prevent inflammation during chronic pancreatic disease.

\section{ACKNOWLEDGMENTS}

The authors thank Dr. Esder Lee and Prof. Ki-Ho Song (Department of Internal Medicine, College of Medicine, the Catholic University of Korea, Seoul, Korea) for their valuable initial support for the isolation of PSCs. Part of this study was presented at the Joint Conference of the Society for Free Radical Research and the Society of Nutrition and Food Science (SFRR-Europe/SNFS Conference), held at the University of Hohenheim, Stuttgart, Germany, September 2 to 4 , 2015. The abstract of the presentation was published in Free Radical Biology and Medicine 86 (Supplement 1) S22, 2015 (Abstract Number PP9).

\section{CONFLICTS OF INTEREST}

No potential conflicts of interest were disclosed.

\section{ORCID}

Sun Ah Chung, https://orcid.org/0000-0001-6061-8054 Joo Weon Lim, https://orcid.org/0000-0001-7483-3820 Hyeyoung Kim, https://orcid.org/0000-0002-7019-917X

\section{REFERENCES}

1. Singh VK, Yadav D, Garg PK. Diagnosis and management of chronic pancreatitis: a review. JAMA 2019;322:2422-34.

2. Majumder S, Chari ST. Chronic pancreatitis. Lancet 2016;387:1957-66

3. Masamune A, Watanabe T, Kikuta K, Shimosegawa T. Roles of pancreatic stellate cells in pancreatic inflammation and fibrosis. Clin Gastroenterol Hepatol 2009;7(11 Suppl):S48-54.

4. Marra F. Renaming cytokines: MCP-1, major chemokine in pancreatitis. Gut 2005;54:1679-81.

5. Uchida M, Ito T, Nakamura T, Igarashi H, Oono T, Fujimori N, et al. ERK pathway and sheddases play an essential role in ethanol-induced CX3CL1 release in pancreatic stellate cells. Lab Invest 2013;93:41-53.

6. Yasuda M, Ito T, Oono T, Kawabe K, Kaku T, Igarashi H, et al. Fractalkine and TGF- $\beta 1$ levels reflect the severity of chronic pancreatitis in humans. World J Gastroenterol 2008;14:6488-95.

7. Jones BA, Beamer M, Ahmed S. Fractalkine/CX3CL1: a potential new target for inflammatory diseases. Mol Interv 2010;10:26370.
8. Mews P, Phillips P, Fahmy R, Korsten M, Pirola R, Wilson J, et al. Pancreatic stellate cells respond to inflammatory cytokines: potential role in chronic pancreatitis. Gut 2002;50:535-41.

9. Jang JH, Yang ES, Min KJ, Kwon TK. Inhibitory effect of butein on tumor necrosis factor- $\alpha$-induced expression of cell adhesion molecules in human lung epithelial cells via inhibition of reactive oxygen species generation, NF- $\mathrm{BB}$ activation and Akt phosphorylation. Int J Mol Med 2012;30:1357-64.

10. Fan J, Frey RS, Rahman A, Malik AB. Role of neutrophil NADPH oxidase in the mechanism of tumor necrosis factor-alpha -induced NF-kB activation and intercellular adhesion molecule-1 expression in endothelial cells. J Biol Chem 2002;277:3404-11.

11. Scott DL, Kingsley GH. Tumor necrosis factor inhibitors for rheumatoid arthritis. N Engl J Med 2006;355:704-12.

12. Masamune A, Suzuki N, Kikuta K, Satoh M, Satoh K, Shimosegawa T. Curcumin blocks activation of pancreatic stellate cells. J Cell Biochem 2006;97:1080-93.

13. Jerrells TR, Vidlak D, Strachota JM. Alcoholic pancreatitis: mechanisms of viral infections as cofactors in the development of acute and chronic pancreatitis and fibrosis. J Leukoc Biol 2007;81:430-9.

14. Fortier ME, Kent S, Ashdown H, Poole S, Boksa P, Luheshi GN. The viral mimic, polyinosinic:polycytidylic acid, induces fever in rats via an interleukin-1-dependent mechanism. Am J Physiol Regul Integr Comp Physiol 2004;287:R759-66.

15. Masamune A, Kikuta K, Watanabe T, Satoh K, Satoh A, Shimosegawa T. Pancreatic stellate cells express Toll-like receptors. J Gastroenterol 2008;43:352-62.

16. Kim H, Yang E, Lee J, Kim SH, Shin JS, Park JY, et al. Doublestranded RNA mediates interferon regulatory factor 3 activation and interleukin- 6 production by engaging Toll-like receptor 3 in human brain astrocytes. Immunology 2008;124:480-8.

17. Yang CS, Kim JJ, Lee SJ, Hwang JH, Lee CH, Lee MS, et al. TLR3-triggered reactive oxygen species contribute to inflammatory responses by activating signal transducer and activator of transcription-1. J Immunol 2013;190:6368-77.

18. Hirono K, Imaizumi T, Aizawa T, Watanabe S, Tsugawa K, Shiratori $\mathrm{T}$, et al. Endothelial expression of fractalkine (CX3CL1) is induced by Toll-like receptor 3 signaling in cultured human glomerular endothelial cells. Mod Rheumatol 2020;30:1074-81.

19. Weldon SM, Mullen AC, Loscher CE, Hurley LA, Roche HM. Docosahexaenoic acid induces an anti-inflammatory profile in lipopolysaccharide-stimulated human THP-1 macrophages more effectively than eicosapentaenoic acid. J Nutr Biochem 2007;18:250-8.

20. Calder PC, Zurier RB. Polyunsaturated fatty acids and rheumatoid arthritis. Curr Opin Clin Nutr Metab Care 2001;4:11521.

21. Yaqoob P, Calder PC. N-3 polyunsaturated fatty acids and inflammation in the arterial wall. Eur J Med Res 2003;8:337-54.

22. Chen W, Esselman WJ, Jump DB, Busik JV. Anti-inflammatory effect of docosahexaenoic acid on cytokine-induced adhesion molecule expression in human retinal vascular endothelial cells. Invest Ophthalmol Vis Sci 2005;46:4342-7. 
23. Ryu GR, Lee E, Chun HJ, Yoon KH, Ko SH, Ahn YB, et al. Oxidative stress plays a role in high glucose-induced activation of pancreatic stellate cells. Biochem Biophys Res Commun 2013;439:258-63.

24. Lee S, Jeong YK, Lim JW, Kim H. Docosahexaenoic acid inhibits expression of fibrotic mediators in mice with chronic pancreatitis. J Cancer Prev 2019;24:233-9.

25. Jeong YK, Lee S, Lim JW, Kim H. Docosahexaenoic acid inhibits cerulein-induced acute pancreatitis in rats. Nutrients 2017;9:744.

26. Saurer L, Reber P, Schaffner T, Büchler MW, Buri C, Kappeler A, et al. Differential expression of chemokines in normal pancreas and in chronic pancreatitis. Gastroenterology 2000;118:356-67.

27. Inoue M, Ino Y, Gibo J, Ito T, Hisano T, Arita Y, et al. The role of monocyte chemoattractant protein-1 in experimental chronic pancreatitis model induced by dibutyltin dichloride in rats. Pancreas 2002;25:e64-70.

28. Naik E, Dixit VM. Mitochondrial reactive oxygen species drive proinflammatory cytokine production. J Exp Med 2011;208:41720.

29. Drake IM, Mapstone NP, Schorah CJ, White KL, Chalmers DM, Dixon MF, et al. Reactive oxygen species activity and lipid peroxidation in Helicobacter pylori associated gastritis: relation to gastric mucosal ascorbic acid concentrations and effect of $\mathrm{H}$ pylori eradication. Gut 1998;42:768-71.

30. Cominelli F. Cytokine-based therapies for Crohn's disease--new paradigms. N Engl J Med 2004;351:2045-8.

31. Reuter S, Gupta SC, Chaturvedi MM, Aggarwal BB. Oxidative stress, inflammation, and cancer: how are they linked? Free Radic Biol Med 2010;49:1603-16.

32. Nakahira K, Haspel JA, Rathinam VA, Lee SJ, Dolinay T, Lam $\mathrm{HC}$, et al. Autophagy proteins regulate innate immune responses by inhibiting the release of mitochondrial DNA mediated by the NALP3 inflammasome. Nat Immunol 2011;12:222-30.

33. Zhou R, Yazdi AS, Menu P, Tschopp J. A role for mitochondria in NLRP3 inflammasome activation. Nature 2011;469:221-5.

34. Madamanchi NR, Runge MS. Mitochondrial dysfunction in atherosclerosis. Circ Res 2007;100:460-73.

35. Dikalov S. Cross talk between mitochondria and NADPH oxidases. Free Radic Biol Med 2011;51:1289-301.

36. Hernández-Aguilera A, Rull A, Rodríguez-Gallego E, RieraBorrull M, Luciano-Mateo F, Camps J, et al. Mitochondrial dysfunction: a basic mechanism in inflammation-related noncommunicable diseases and therapeutic opportunities. Mediators Inflamm 2013;2013:135698.

37. López-Armada MJ, Riveiro-Naveira RR, Vaamonde-García C, Valcárcel-Ares MN. Mitochondrial dysfunction and the inflammatory response. Mitochondrion 2013;13:106-18.

38. Salminen A, Ojala J, Kaarniranta K, Kauppinen A. Mitochondrial dysfunction and oxidative stress activate inflammasomes: impact on the aging process and age-related diseases. Cell Mol Life Sci 2012;69:2999-3013.

39. Lawrence $\mathrm{T}$. The nuclear factor NF-kB pathway in inflammation. Cold Spring Harb Perspect Biol 2009;1:a001651.

40. Morgan MJ, Liu ZG. Crosstalk of reactive oxygen species and
NF-кB signaling. Cell Res 2011;21:103-15.

41. Huang H, Liu Y, Daniluk J, Gaiser S, Chu J, Wang H, et al. Activation of nuclear factor- $\kappa B$ in acinar cells increases the severity of pancreatitis in mice. Gastroenterology 2013;144:20210.

42. Hsu H, Shu HB, Pan MG, Goeddel DV. TRADD-TRAF2 and TRADD-FADD interactions define two distinct TNF receptor 1 signal transduction pathways. Cell 1996;84:299-308.

43. Satoh A, Gukovskaya AS, Nieto JM, Cheng JH, Gukovsky I, Reeve JR Jr, et al. PKC-delta and -epsilon regulate NF$\kappa \mathrm{B}$ activation induced by cholecystokinin and TNF- $\alpha$ in pancreatic acinar cells. Am J Physiol Gastrointest Liver Physiol 2004;287:G582-91.

44. Masamune A, Sakai Y, Kikuta K, Satoh M, Satoh A, Shimosegawa T. Activated rat pancreatic stellate cells express intercellular adhesion molecule-1 (ICAM-1) in vitro. Pancreas 2002;25:78-85.

45. Reisinger S, Khan D, Kong E, Berger A, Pollak A, Pollak DD. The poly(I:C)-induced maternal immune activation model in preclinical neuropsychiatric drug discovery. Pharmacol Ther 2015;149:21326.

46. Zhu S, Xu X, Liu K, Gu Q, Wei F, Yang X. PAPep inhibits secretion of poly(I:C)-induced inflammatory cytokines and ICAM1 expression in corneal fibroblasts by suppressing the NF-KB/ p38 pathway. J Ocul Pharmacol Ther 2018;34:395-402.

47. Liu D, Darville M, Eizirik DL. Double-stranded ribonucleic acid (RNA) induces beta-cell Fas messenger RNA expression and increases cytokine-induced beta-cell apoptosis. Endocrinology 2001;142:2593-9.

48. Hu F, Lou N, Jiao J, Guo F, Xiang H, Shang D. Macrophages in pancreatitis: mechanisms and therapeutic potential. Biomed Pharmacother 2020;131:110693.

49. Cavestro GM, Zuppardo RA, Bertolini S, Sereni G, Frulloni L, Okolicsanyi $S$, et al. Connections between genetics and clinical data: role of MCP-1, CFTR, and SPINK-1 in the setting of acute, acute recurrent, and chronic pancreatitis. Am J Gastroenterol 2010;105:199-206.

50. Ishibashi T, Zhao H, Kawabe K, Oono T, Egashira K, Suzuki K, et al. Blocking of monocyte chemoattractant protein-1 (MCP1) activity attenuates the severity of acute pancreatitis in rats. $J$ Gastroenterol 2008;43:79-85.

51. Uchida $\mathrm{M}$, Ito $\mathrm{T}$, Nakamura $\mathrm{T}$, Hijioka $\mathrm{M}$, Igarashi $\mathrm{H}$, Oono $\mathrm{T}$, et al. Pancreatic stellate cells and CX3CR1: occurrence in normal pancreas and acute and chronic pancreatitis and effect of their activation by a CX3CR1 agonist. Pancreas 2014;43:708-19.

52. Song EA, Lim JW, Kim H. Docosahexaenoic acid inhibits IL-6 expression via PPAR $\gamma$-mediated expression of catalase in cerulein-stimulated pancreatic acinar cells. Int J Biochem Cell Biol 2017;88:60-8.

53. Masamune A, Kikuta K, Satoh M, Sakai Y, Satoh A, Shimosegawa T. Ligands of peroxisome proliferator-activated receptor-gamma block activation of pancreatic stellate cells. J Biol Chem 2002;277:141-7.

54. Wan Y, Evans RM. Rosiglitazone activation of PPARgamma 
suppresses fractalkine signaling. J Mol Endocrinol 2010;44:13542.

55. Kastl L, Sauer SW, Ruppert T, Beissbarth T, Becker MS, Süss D, et al. TNF- $\alpha$ mediates mitochondrial uncoupling and enhances ROS-dependent cell migration via NF-кB activation in liver cells. FEBS Lett 2014;588:175-83.

56. Schulze-Osthoff K, Bakker AC, Vanhaesebroeck B, Beyaert R, Jacob WA, Fiers W. Cytotoxic activity of tumor necrosis factor is mediated by early damage of mitochondrial functions. Evidence for the involvement of mitochondrial radical generation. J Biol Chem 1992;267:5317-23.

57. Corda S, Laplace C, Vicaut E, Duranteau J. Rapid reactive oxygen species production by mitochondria in endothelial cells exposed to tumor necrosis factor-alpha is mediated by ceramide. Am J Respir Cell Mol Biol 2001;24:762-8.

58. Unger BL, Ganesan S, Comstock AT, Faris AN, Hershenson MB, Sajjan US. Nod-like receptor $X-1$ is required for rhinovirusinduced barrier dysfunction in airway epithelial cells. J Virol 2014;88:3705-18.

59. Karlsson M, Kurz T, Brunk UT, Nilsson SE, Frennesson Cl. What does the commonly used DCF test for oxidative stress really show? Biochem J 2010;428:183-90.

60. Kim S, Kim C, Park S. Mdivi-1 protects adult rat hippocampal neural stem cells against palmitate-induced oxidative stress and apoptosis. Int J Mol Sci 2017;18:1947.

61. Sakamoto Y, Yano T, Hanada Y, Takeshita A, Inagaki F, Masuda $\mathrm{S}$, et al. Vancomycin induces reactive oxygen species-dependent apoptosis via mitochondrial cardiolipin peroxidation in renal tubular epithelial cells. Eur J Pharmacol 2017;800:48-56.

62. Tian L, Lu ZP, Cai BB, Zhao LT, Qian D, Xu QC, et al. Activation of pancreatic stellate cells involves an EMT-like process. Int $\mathrm{J}$ Oncol 2016;48:783-92.

63. Haber PS, Keogh GW, Apte MV, Moran CS, Stewart NL,
Crawford DH, et al. Activation of pancreatic stellate cells in human and experimental pancreatic fibrosis. Am J Pathol 1999;155:1087-95.

64. Eum HR. Effect of docosahexaenoic acid on expression of fibrotic proteins in pancreatic stellate cells [thesis]. Seoul: Yonsei University; 2017.

65. Kim H, Seo JY, Roh KH, Lim JW, Kim KH. Suppression of NF$\kappa \mathrm{B}$ activation and cytokine production by $\mathrm{N}$-acetylcysteine in pancreatic acinar cells. Free Radic Biol Med 2000;29:674-83.

66. Clementi ME, Lazzarino G, Sampaolese B, Brancato A, Tringali G. DHA protects PC12 cells against oxidative stress and apoptotic signals through the activation of the NFE2L2/HO-1 axis. Int J Mol Med 2019;43:2523-31.

67. Oguro A, Fujita K, Ishihara Y, Yamamoto M, Yamazaki T. DHA and its metabolites have a protective role against methylmercuryinduced neurotoxicity in mouse primary neuron and SH-SY5Y cells. Int J Mol Sci 2021;22:3213.

68. Li G, Li Y, Xiao B, Cui D, Lin Y, Zeng J, et al. Antioxidant activity of docosahexaenoic acid (DHA) and its regulatory roles in mitochondria. J Agric Food Chem 2021;69:1647-55.

69. Shin SK, Kim JH, Lee JH, Son YH, Lee MW, Kim HJ, et al. Docosahexaenoic acid-mediated protein aggregates may reduce proteasome activity and delay myotube degradation during muscle atrophy in vitro. Exp Mol Med 2017;49:e287.

70. D’Eliseo D, Di Renzo L, Santoni A, Velotti F. Docosahexaenoic acid (DHA) promotes immunogenic apoptosis in human multiple myeloma cells, induces autophagy and inhibits STAT3 in both tumor and dendritic cells. Genes Cancer 2017;8:426-37.

71. Skender B, Hofmanová J, Slavík J, Jelínková I, Machala M, Moyer MP, et al. DHA-mediated enhancement of TRAIL-induced apoptosis in colon cancer cells is associated with engagement of mitochondria and specific alterations in sphingolipid metabolism. Biochim Biophys Acta 2014;1841:1308-17. 